\title{
Remote sensing observations of winter phytoplankton blooms southwest of the Luzon Strait in the South China Sea
}

\author{
Dan-Ling Tang ${ }^{1, *}$, I-Hsun Ni ${ }^{2}$, Dana R. Kester ${ }^{3}$, Frank E. Müller-Karger ${ }^{4}$ \\ ${ }^{1}$ Department of Biology, The Hong Kong University of Science \& Technology, Hong Kong; and Department of Biology, \\ Jinan University, Guangzhou, China \\ ${ }^{2}$ Department of Biology, The Hong Kong University of Science \& Technology, Hong Kong, China \\ ${ }^{3}$ Graduate School of Oceanography, University of Rhode Island, Narragansett, Rhode Island, USA \\ ${ }^{4}$ Department of Marine Science, University of South Florida, St. Petersburg, Florida, USA
}

\begin{abstract}
The Luzon Strait is a channel between the Philippine Sea and the South China Sea. This area is traditionally classified as an oligotrophic zone with low primary productivity. Even so, high concentrations of pigment were detected $100 \mathrm{~km}$ southwest of the Strait through analysis of historical Coastal Zone Color Scanner (CZCS) data that the Nimbus-7 satellite collected during the winters of 1979 to 1986. These blooms were observed in December 1979, February 1983, February 1985, and January 1986, when sea surface temperatures measured with the National Oceanic and Atmospheric Administration's (NOAAs) Advanced Very High Resolution Radiometer (AVHRR) were 23 to $25^{\circ} \mathrm{C}$, the lowest in the year. High pigment concentrations ( 1 to $3 \mathrm{mg} \mathrm{m}^{-3}$ ) persisted for at least 1 to $3 \mathrm{wk}$ and extended over areas of about $100 \times 200 \mathrm{~km}^{2}$. Results of oceanographic survey published in 1995 also showed that a high chlorophyll a concentration $\left(\sim 2.0 \mathrm{mg} \mathrm{m}^{-3}\right)$ occurred in the winter of 1980 in this region. The winter phytoplankton blooms in this area appeared to be related to upwelling, which brings mutrients to the surface waters and lowers the water ternperature.
\end{abstract}

KEY WORDS: Phytoplankton blooms · CZCS · Upwelling · Luzon Strait · South China Sea

\section{INTRODUCTION}

The Luzon Strait, a channel between the Philippine Sea and the South China Sea (SCS), is $350 \mathrm{~km}$ wide and $2500 \mathrm{~m}$ at the deepest point (Farris \& Wimbush 1996). It is the only important channel for the exchange of the SCS deep water with the waters of the Western Philippine Sea in the open Pacific Ocean (Sverdrup et al. 1946). All other channels connecting the SCS with the surrounding ocean waters are either shallow or narrow (Gong et al. 1992). Many oceanographic studies have been conducted in this region (Shaw 1991, Gong et al. 1992, Farris \& Wimbush 1996). However, biological studies, particularly for phytoplankton pigment concentrations, are lacking (Huang \& Chen 1989). In this study, historical Coastal Zone Color Scan-

•E-mail: lingzist@ust.hk ner (CZCS)-derived pigment concentrations around the Luzon Strait were examined, and winter phytoplankton blooms southwest of the Strait were identified during certain years.

Ocean color data from the CZCS onboard the Nimbus-7 satellite, which operated from 1978 to 1986 , have been used to interpret biological processes in the ocean (Müller-Karger et al. 1989, Barale \& Schlittenhardt 1993) and in the Chinese seas (Tang et al. 1998). Advanced Very High Resolution Radiometer (AVHRR) images from the National Oceanic and Atmospheric Administration (NOAA) satellites have also been used for studies of spatial and temporal changes in sea surface temperature (SST) in the north of the SCS (Tang \& Ni 1996). Analyzing CZCS images, Kester \& Fox (1993) noted high pigments in the southwestern section of the Luzon Strait ( 17 to $21^{\circ} \mathrm{N}, 118$ to $121^{\circ} \mathrm{E}$ ) in December 1979. Cruise data (Fan 1985) also indicated that chloro- 
phyll a (chl a) was high (2.17 $\left.\mathrm{mg} \mathrm{m}^{-3}\right)$ west of the Philippines $\left(17^{\circ} \mathrm{N}, 118^{\circ} \mathrm{E}\right)$ from September to $\mathrm{No}$ vember 1980 .

The southwestern area of the Luzon Strait is traditionally classified as an oligotrophic zone with low primary productivity (Pauly \& Christensen 1993). By examining the CZCS data to characterize the phytoplankton variability in coastal waters off China, Tang et al. (1998) found that pigment concentrations around the Luzon Strait were usually low $\left(<0.2 \mathrm{mg} \mathrm{m}^{-3}\right)$. However, occasionally, high values occurred southwest of the Strait during several winters from 1979 to 1986 (the duration of the CZCS mission). The location of the high pigment concentration is about $150 \mathrm{~km}$ from the coast, where water depths are generally greater than $2500 \mathrm{~m}$. High pigment concentrations occurred only in winter, but not in spring, when phytoplankton blooms usually occur in the northern SCS. These preliminary observations prompted us to examine all the historical CZCS data and to search for the available oceanographic data in this region in order to determine the location, frequency, duration and size of previous phytoplankton bloom occurrences and to investigate the factors that may cause these blooms.

The spring phytoplankton bloom is important to the economy of the oceans, with respect to trophodynamics and fisheries, and to global biogeochemical cycles (Townsend et al. 1994). The spring phytoplankton bloom in temperate and boreal waters represents a pulsed source of organic carbon that is important to ecosystem productivity and carbon flux in oceans all over the world (Townsend et al. 1992). It is generaily accepted that seasonal development of a thermocline, in combination with increasing solar elevation in spring, is requisite for the development of the bloom in shelf and open ocean environments (Riley 1957). How- ever, Townsend et al. $(1992,1994)$ reported results for the offshore waters of the Gulf of Maine, suggesting the spring bloom could precede the onset of vertical water column stability, and may even be a contributing factor in the development of the thermocline. They suggested that blooms can begin following the winter period of deep convection, and prior to the vernal development of stratification, provided that wind speed is below a certain, predictable threshold. The present study examines winter phytoplankton blooms in a tropical region where the water is deeper than $2500 \mathrm{~m}$.

\section{METHODS}

Satellite data. CZCS-derived pigment data: CZCS data collected from November 1978 to June 1986 were used in this study. Images with $4 \mathrm{~km}$ spatial resolution, obtained from National Aeronautics and Space Administration (NASA) in the USA and archived at the remote sensing laboratory at the University of South Florida (USF) were utilized. Available individual $2 \mathrm{~min}$ scenes were screened with the BROWSE quick-look facility (developed at the NASA Goddard Space Flight Center). All valid data covering the study area (15 to $23^{\circ} \mathrm{N}$, 110 to $130^{\circ} \mathrm{E}$ ) (Fig. 1) were processed with Digital System Processing (DSP) software (developed by the University of Miami). Standard atmospheric biooptical algorithms (Gordon et al. 1983, 1988) were used to correct for aerosols, cloud cover, and sun glint. Pigment concentration, an approximate quantity that incorporates the effects of chl a plus phaeopigments and colored dissolved organic matter (CDOM) on ocean color, was derived from ratios of blue $(443 \mathrm{~nm})$ or blue-green $(520 \mathrm{~nm})$ water-leaving radiance to green radiance $(550 \mathrm{~nm})$.

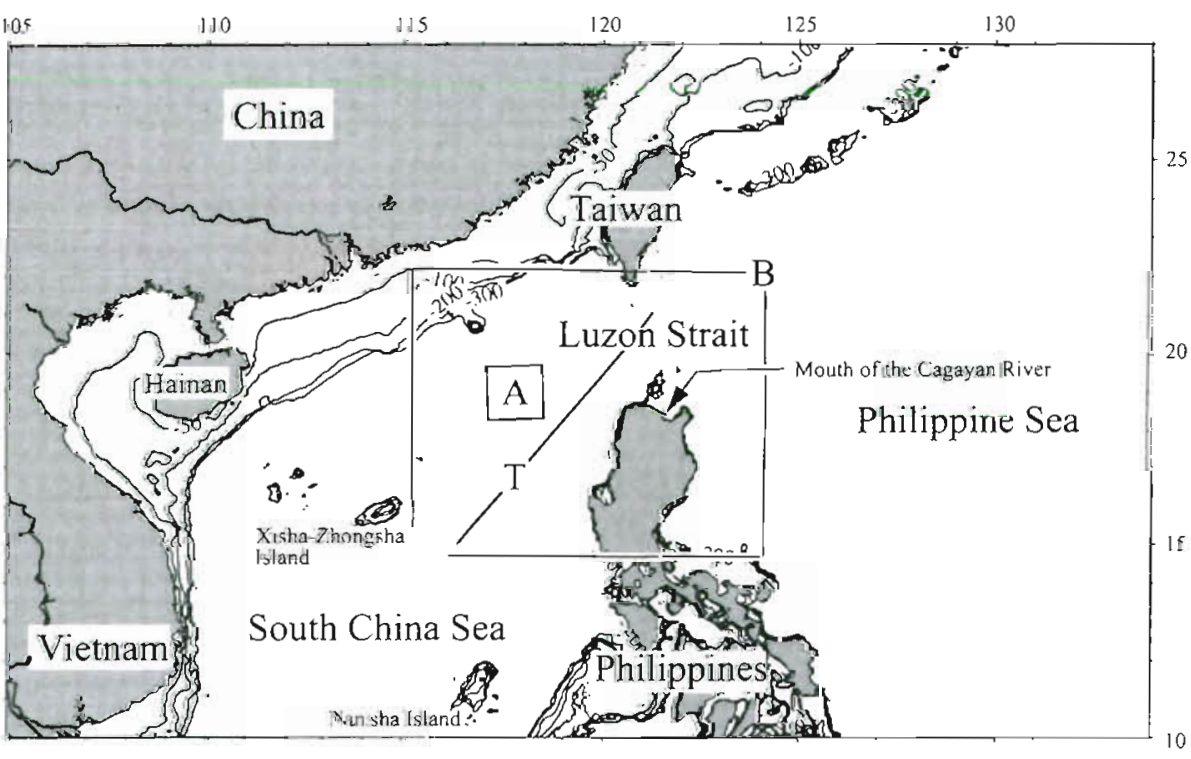

Fig. 1. Study area with 100,200 and $300 \mathrm{~m}$ isobaths, and satellite data sampling area. Box $A$ is at the center of the phytoplankton bloom's region in the SCS. Box $B$ is the geographic window for oceanographic data searching and sampling. Transect $T$ is for temperature and salinity data sampling 
Weekly and monthly composite images were computed based on the arithmetic average of cloud-free pixels using IDL (Interactive Data Language developed by Research Systems Inc.). All images had been remapped using a cylindrical equidistant projection before the averaged composites were generated. The final spatial resolution of the images was approximately $6 \mathrm{~km}$ per pixel.

AVHRR-derived water temperature data: The principal data set that we used for SST was obtained from the NOAA series of satellites. The NOAA satellites operate in a near-polar sun-synchronous orbit at a height of about $850 \mathrm{~km}$ and provide a global coverage roughly twice daily. The AVHRR instrument has 5 channels with center wavelengths ranging from visible $(0.62 \mu \mathrm{m})$, to near-infrared $(0.91 \mu \mathrm{m})$, to infrared $(3-7,10.8,12.0 \mu \mathrm{m})$. SSTs were derived from these bands.

Weekly composite AVHRR data from 1981 to 1986 were obtained from NASA. These data were processed with DSP and the Generic Mapping Tools (GMT) software (Wessel \& Smith 1991, 1995). In addition, NASA Pathfinder SST images with $9 \mathrm{~km}$ spatial resolution were studied for the Luzon Strait region during the winter season; the images were obtained from the Jet Propulsion Laboratory (JPL) Physical Oceanography Distributed Active Archive Center.

Sampling area: In preliminary screening of CZCS images, high CZCS pigment concentrations were detected in almost the same location during the winter. We therefore selected a single study site at the center of the bloom region $\left(18.5^{\circ} \mathrm{N}, 118.5^{\circ} \mathrm{E}\right)$ for data sampling, which is in the southwest of the Luzon Strait in the SCS (Box A in Fig. 1). This square area covers approximately $100 \times 100 \mathrm{~km}(17 \times 17$ pixels with 289 CZCS data points). Two minute scenes of CZCS data and SST data (weekly composites) were sampled to calculate mean pigment and temperature values from this square area for the period 1978-1986 to render a time series.

Oceanographic data. Historical water temperature, salinity and oxygen data in the study area were obtained from the Global Ocean Observation Database (GOODBase) that was established by Scripps Institution of Oceanography and NOAA.

A geographic window $\left(22^{\circ} \mathrm{N}, 115^{\circ} \mathrm{E}\right.$ to $\left.15^{\circ} \mathrm{N}, 124^{\circ} \mathrm{E}\right)$ in the north of the SCS was selected for GOODBase data searching and sampling (Box B in Fig. 1). We examined the GOODBase data for the study area during the 1974-1994 period. We could not find temperature and salinity data for the winters in the area during the CZCS mission, but we found data along 1 transect (Transect T in Fig. 1) in the region for February in 1976 and in 1977 .

\section{RESULTS}

\section{High pigment concentrations southwest of the Luzon Strait in winter}

During most of the year, pigment concentrations southwest of the Luzon Strait were low $\left(<0.2 \mathrm{mg} \mathrm{m}^{-3}\right)$ and similar to the values in the surrounding areas. A typical monthly composite image of pigment concentration around the Luzon Strait is shown in Fig. 2, using May 1980 as an example.

We detected high pigment concentration values southwest of the Luzon Strait during some winters of the CZCS mission (1979-1986), but we did not find the same phenomenon in spring, summer or autumn. If concentrations were greater than $1.0 \mathrm{mg} \mathrm{m}^{-3}$, we took

Fig. 2. CZCS monthly composite image (May 1980, as an example), showing the distribution of pigment concentration in the Luzon Strait and in the surrounding areas. There was no phytoplankton bloom in this area in this month

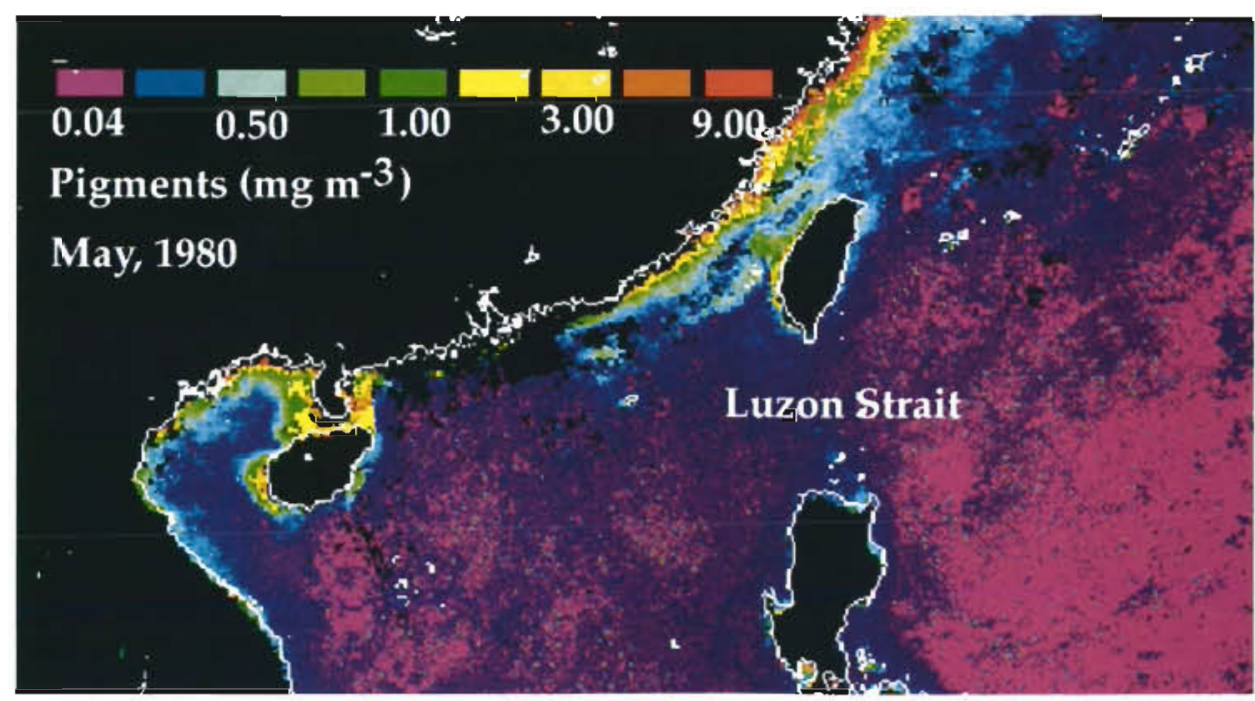


them as bloom conditions for this region. In December 1979 (Fig. 3a), pigment concentrations southwest of the Luzon Strait, centered at $19^{\circ} \mathrm{N}, 118.5^{\circ} \mathrm{E}$, were high, indicating a phytoplankton bloom. This bloom region was large $\left(100 \times 200 \mathrm{~km}^{2}\right)$ with a pigment concentration of approximately $2.5 \mathrm{mg} \mathrm{m}^{-3}$ in the center of the bloom. In the surrounding area of the bloom, the pigment concentration was $0.2 \mathrm{mg} \mathrm{m}^{-3}$. Phytoplankton blooms appeared again in January and February 1983 (Fig. 3b) in the west of the Luzon Strait centered at $20^{\circ} \mathrm{N}, 119^{\circ} \mathrm{E}$. The bloom area moved further north in comparison with winter blooms in other years. The pig-

\section{a December 1979}
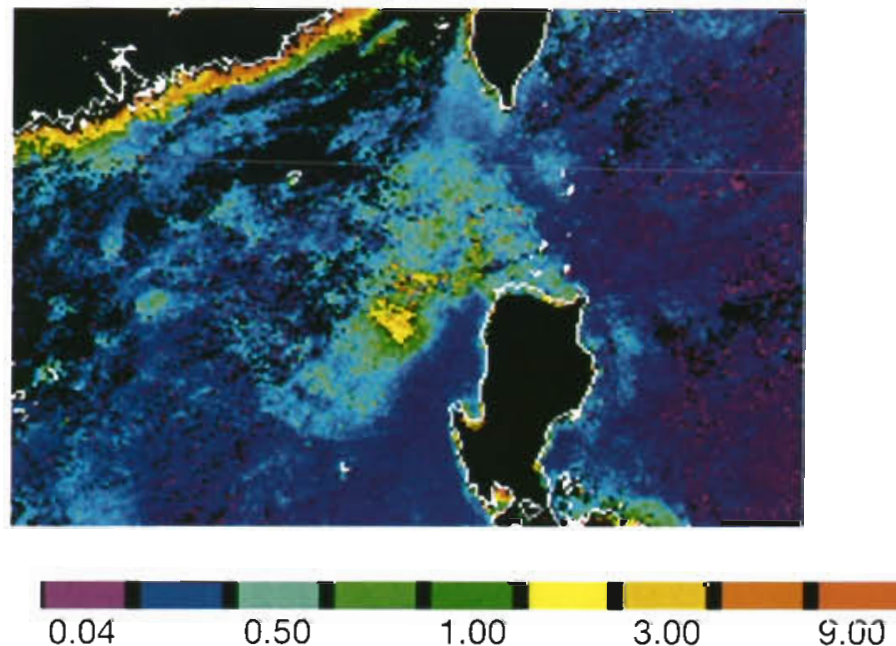

b February 1983

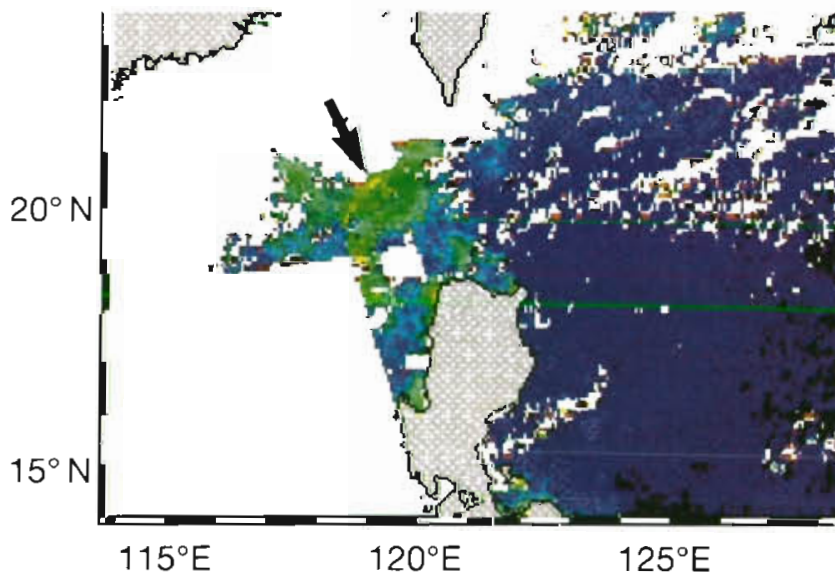

c February 1985
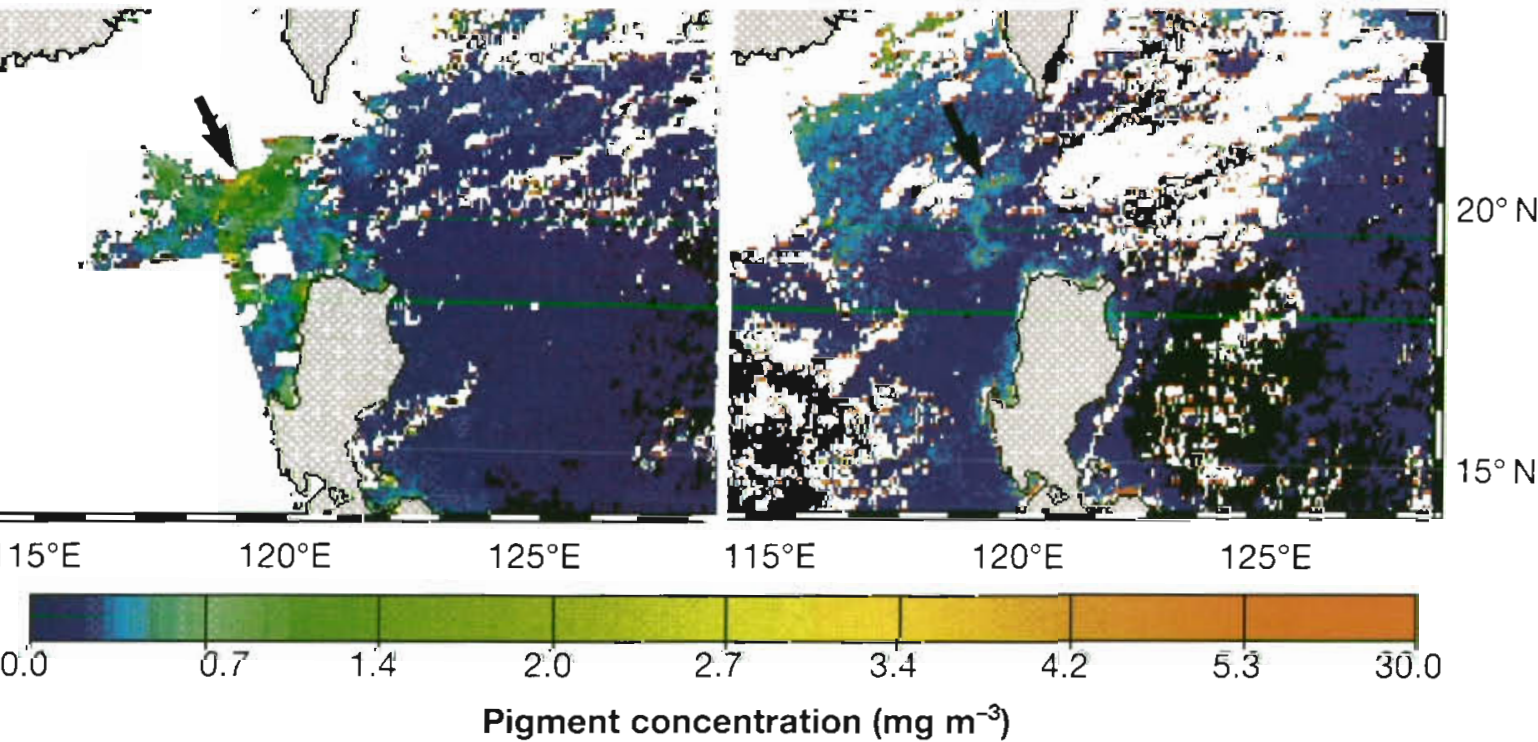

Fig. 3. CZCS images showing winter phytoplankton blooms southwest of the Luzon Strait. Pigment concentrations (mg m ${ }^{-3}$ ) are color coded in the plates. In (a) and (d) (DSP software), the coastline is marked white; land, clouds and missing data are marked black. In (b) and (c) (GMT software), the coastline is marked black; clouds and missing data are marked white. Arrows: high pigment concentration. (a to c) CZCS monthly composite CZCS images in (a) December 1979, (b) February 1983 and (c) 1985, respectively. (d) Weekly composite CZCS image at the end of January 1986 with a C-shaped high pigment concentration (yellow 


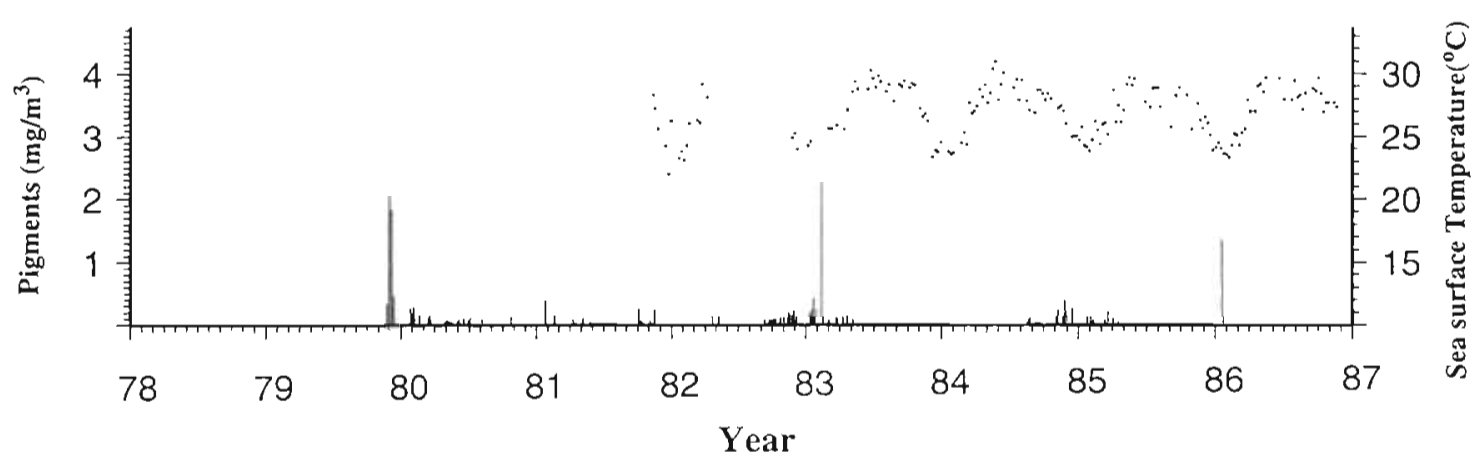

Fig. 4. Time series of pigment concentration ( 2 min scenes shown as vertical bars) and sea surface temperature (weekly composite, indicated by data points) in the box during the period of the CZCS mission. Three phytoplankton blooms are evident in December 1979, February 1983, and January 1986, when sea surface water temperatures were low $\left(23\right.$ to $\left.25^{\circ} \mathrm{C}\right)$. There were no CZCS data during the winter of 1984, and gaps in the CZCS data set may have missed blooms in 1981 and 1982

construct these composite CZCS images, we found that these blooms persisted for about 1 to $3 \mathrm{wk}$.

\section{Time series of pigment concentrations and SST}

The time series of pigment concentrations and SST of the sampling area (Box A in Fig. 1) west of the Luzon Strait is shown in Fig. 4. A phytoplankton bloom can be identified in the last week of November 1979. The pigment concentration reached about $2.2 \mathrm{mg} \mathrm{m}^{-3}$ in the first week in December, lasted about $3 \mathrm{wk}$ and then decreased in the third week of December. We do not have SST data for that month. A phytoplankton bloom was detected again in mid-February 1983, with the pigment concentration being about $2.5 \mathrm{mg} \mathrm{m}^{-3}$ and the SST about $25^{\circ} \mathrm{C}$. The pigment concentration was lower than $0.3 \mathrm{mg} \mathrm{m}^{-3}$ before and after the February 1983 bloom. Another pigment concentration peak was detected during the fourth week in January 1986, when the water temperature was the lowest (about $23^{\circ} \mathrm{C}$ ) for that year. We do not know how long this bloom extended because there was only 1 available satellite image for that month. There were very limited CZCS data for the winter of 1981 and 1982, and there were no data for the winter of 1984 . We have data for the winter of 1985, with a $3 \mathrm{wk}$ gap of missing data from the end of December to the beginning of January 1985. SST varied from 22 to $31^{\circ} \mathrm{C}$ in the year in that area (Fig. 4). Pigment blooms only occurred when SST was low $\left(23\right.$ to $\left.25^{\circ} \mathrm{C}\right)$.

CZCS data were not acquired continuously in this area and there are substantial gaps in the data. Therefore, we do not know if the phytoplankton bloom occurred every winter during the CZCS mission. It is possible that the high pigment concentrations may have been missed in 1981, 1982 and 1984 (Fig. 4) because CZCS images were unavailable. In some instances, the maximum pigment concentration value may be higher than that showed in Fig. 4. The mean pigment concentration in Fig. 4 is calculated from the sampling box (as in Fig. 1), which covers 289 CZCS pixels. The center location of the winter bloom patch did vary from year to year, so the sampling box might not always include the center of the bloom as in February 1985 and therefore it cannot be shown from Fig. 4. The pigment concentration of the bloom varied also. For example, the value that was detected in February 1985 did not reach $1 \mathrm{mg} \mathrm{m}^{-3}$.

\section{Warm temperature loop pattern west of the Luzon Strait}

When we examined the monthly variation of SST from AVHRR images, we noticed that there were high temperatures west of the Luzon Strait in the north of the SCS in the winter season. Fig. 5 shows an SST

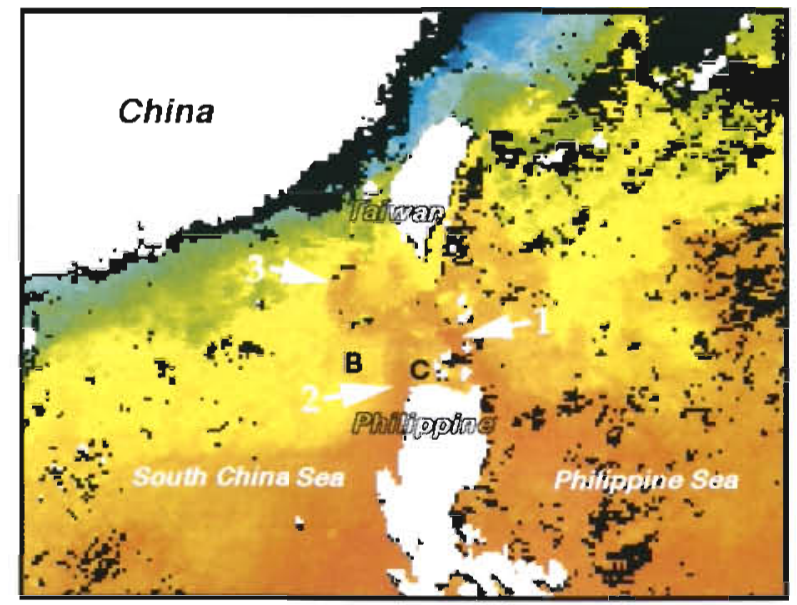

Fig. 5. AVHRR SST image showing the high temperature water loop current intrusion (Arrow 3) west of the Luzon Strait (January 1993). Arrows 1 and 2: The water temperature was high along both the east and west coast of the Philippines, respectively. $\mathrm{B}$ and $\mathrm{C}$ : body of lower water temperature 
image of the Strait in January 1993. The water temperature was high along both the east and west coasts of the Philippines (Arrows 1 and 2 in Fig. 5). These 2 features extend northward and merged together in the Luzon Strait. A body of lower temperature water (' $C$ ' in Fig. 5) between these 2 bodies of coastal water may come from the Cagayan River (Fig. 1). A warm loop was present west of the Strait (Arrow 3), which then turned northeastward to the east of Taiwan. This observation of warm waters extending north of Luzon and a loop or eddy feature indicates the complexity of waters in the Strait, which has been documented by Farris \& Wimbush (1996).

\section{Temperature and salinity in the Luzon Strait}

In an attempt to determine the reason for the formation of these phytoplankton blooms, historical temperature and salinity data were examined, and previous studies in this region were reviewed. Fig. 6 shows the vertical profile of temperature and salinity along Transect $T$ ( $T$ line in Fig. 1) in February 1977. The $y$-axis displays the depths from the surface to a depth of $500 \mathrm{~m}$; the $x$-axis displays the distance along this transect from the southwest sampling station to the northeast sampling station. The water temperature was high $\left(20\right.$ to $23^{\circ} \mathrm{C}$ ) on the surface, but low temperature (below $18^{\circ} \mathrm{C}$ ) waters rose to $50 \mathrm{~m}$ below the surface southwest of the Luzon Strait (located at $600 \mathrm{~km}$ on the $x$-axis of Fig. 6a). At the same location and time, a water mass of high salinity water (more than $34.5 \%$ ) appeared at a depth ranging from 50 to $100 \mathrm{~m}$ southwest of the Strait ( $600 \mathrm{~km}$ on the $x$-axis in Fig. 6b).

\section{DISCUSSION}

\section{Phytoplankton blooms in winter}

Studies of chl a concentration have been conducted in the northern part of the SCS, but very few have been conducted near the Luzon Strait (Huang \& Chen 1989). Chl a concentration was usually low offshore in the SCS, $<0.59 \mathrm{mg} \mathrm{m}^{-3}$ in water adjacent to the XishaZhongsha Islands (Fig. 1) from October to November 1979 (Liu \& Liu 1984). Chl a concentration was low northeast of the Luzon Strait, the mean value was $0.09 \pm 0.06 \mathrm{mg} \mathrm{m}^{-3}$ (Huang \& Chen 1989). Data collected during 4 cruises in northern SCS from fall 1980 to summer 1982 (Fan 1985) indicate that the highest surface chl a (2.17 $\left.\mathrm{mg} \mathrm{m}^{-3}\right)$ was reported west of the Philippines $\left(17^{\circ} \mathrm{N}, 118^{\circ} \mathrm{E}\right)$ from September to November. Kester \& Fox (1993) also reported high pigment values from CZCS images in December 1979. In general, the high pigment values reported in these studies support our results. However, these reports did not indicate the time, duration or size of the high pigment concentrations. No phytoplankton bloom southwest of the Luzon Strait has been reported from ship surveys. Possible reasons for that include: (1) the phytoplankton bloom is far away from the coast, where few offshore biological surveys have been conducted; (2) blooms are very short lived so they cannot be easily detected.

The CZCS-derived pigment includes chl a plus phaeopigments and CDOM. CDOM could influence the CZCS-derived pigment, particularly in the coastal zone (Gordon et al. 1983, 1988, Müller-Karger et al. 1989). However, the high pigment concentrations observed were far from the coast (about $150 \mathrm{~km}$ ), where
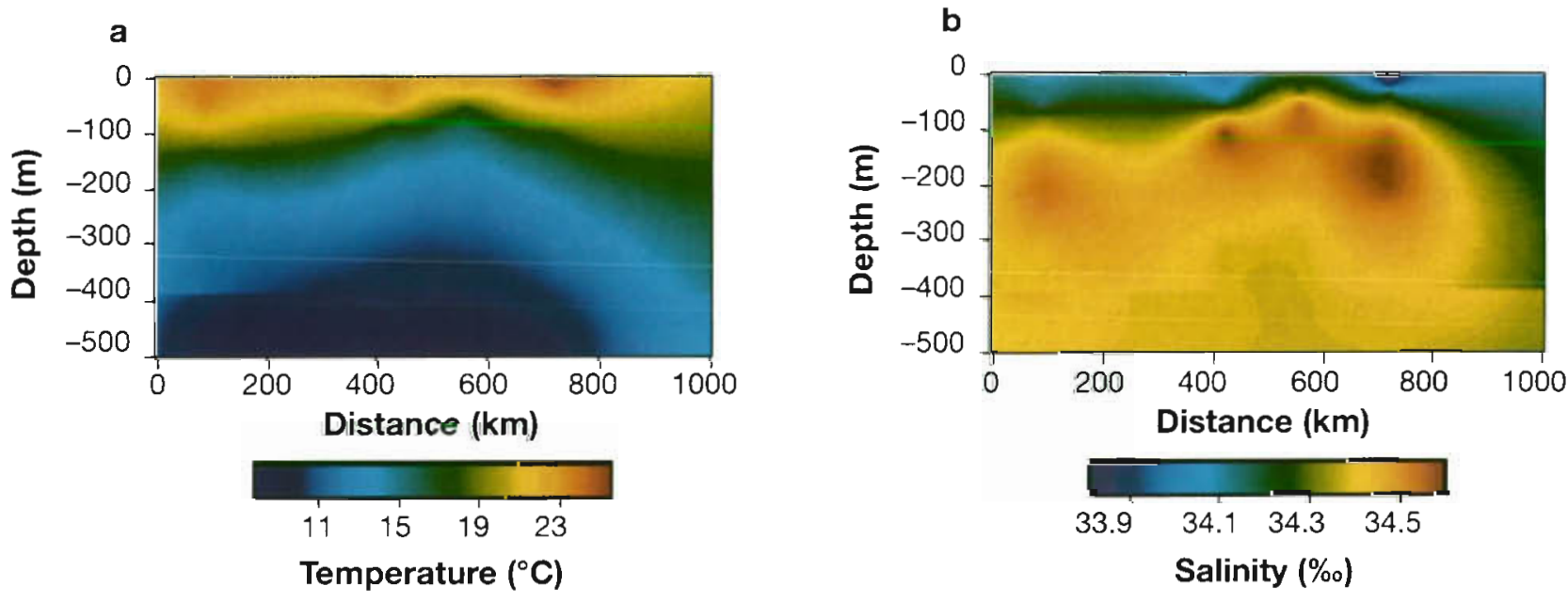

Fig. 6. (a) Temperature and (b) salinity in Transect $T$ in February 1977 . The $y$-axes show depths from the surface to 500 m down, and the $x$-axes display the distance from the beginning of the transect (southwest) to the sampling station (northeast) along the transect. (a) Low temperature water $\left(<18^{\circ} \mathrm{C}\right)$ and (b) high salinity water ( $>34.5 \%$ ) upwelled to surface (50 m deep, $y$-axis) at $600 \mathrm{~km}$ ( $x$-axis) 
the water is very deep (about $3000 \mathrm{~m}$ ). Therefore, the CZCS-derived pigment should be mainly from phytoplankton and not from CDOM in this region.

Table 1 summarizes observed high pigment values southwest of the Luzon Strait from 1979 to 1986. It should be noted that CZCS data available for this region for the winters of 1981, 1982 and 1984 are so limited in number that they cannot tell us if there were phytoplankton blooms in these years.

\section{High chl a concentrations at the subsuriace in the SCS}

Based on 4 ship surveys, Fan (1985) reported that chl a concentration reached $1.27 \mathrm{mg} \mathrm{m}^{-3}$ at a depth of 25 m west of the Philippines from September to November 1980. The chl a concentration was very low $\left(0.09 \pm 0.06 \mathrm{mg} \mathrm{m}^{-3}\right)$ northeast of the Luzon Strait $\left(17^{\circ} 55^{\prime}\right.$ to $20^{\circ} 06^{\prime} \mathrm{N}, 120^{\circ} 55^{\prime}$ to $126^{\circ} 57^{\prime} \mathrm{E}$ ) in June 1984 (Huang \& Chen 1989), and the maximum chl a concentration $\left(0.16 \pm 0.04 \mathrm{mg} \mathrm{m}^{-3}\right)$ was measured at a depth of $100 \mathrm{~m}$, which is the upper boundary of the thermocline. Ship survey data obtained between 1985 and 1990 (Huang 1992) showed vertical variations of chl a in the SCS: the chl a peak appeared at a depth of $75 \mathrm{~m}$ in summer and $50 \mathrm{~m}$ in winter. The chl $a$ content in the western area of the Luzon Strait increased with increasing water depth to $75 \mathrm{~m}$. Based on ship surveys around the Nansha Islands in July 1984, May-June 1985 and April-May 1986, the maximum values $(0.30$ or $0.34 \pm 0.10 \mathrm{mg} \mathrm{m}^{-3}$ ) of chl a were also observed at a $75 \mathrm{~m}$ depth, which is the thermocline (Huang 1988). Therefore, high chl a concentrations in the SCS usually appear in the subsurface waters and maximum chl $a$

Table 1. Phytoplankton bloom recorded southwest of the Luzon Strait during the 1979-1986 period

\begin{tabular}{|c|c|c|c|c|c|}
\hline Date & $\begin{array}{l}\text { Bloom } \\
\text { center }\end{array}$ & $\begin{array}{l}\text { Pigment } \\
\text { value } \\
\left(\mathrm{mg} \mathrm{m}^{-3}\right)\end{array}$ & Fig. & Method & Source \\
\hline $\begin{array}{l}\text { November and } \\
\text { December } 1979\end{array}$ & $\begin{array}{l}18.5^{\circ} \mathrm{N} \\
117.5^{\circ} \mathrm{E}\end{array}$ & 2.5 & $3 a$ & $\begin{array}{l}\text { Pigment } \\
\text { concentration, } \\
\text { CZCS data }\end{array}$ & This study \\
\hline $\begin{array}{l}\text { September to } \\
\text { November } 1980\end{array}$ & $\begin{array}{l}17.0^{\circ} \mathrm{N} \\
118.0^{\circ} \mathrm{E}\end{array}$ & 2.17 & $\begin{array}{l}\text { Text cite } \\
\text { 'Discussion' }\end{array}$ & Chlorophyll a & Fan (1985) \\
\hline February 1983 & $\begin{array}{l}20.0^{\circ} \mathrm{N} \\
119.0^{\circ} \mathrm{E}\end{array}$ & 2.5 & $3 c$ & $\begin{array}{l}\text { Pigment } \\
\text { concentration, } \\
\text { CZCS data }\end{array}$ & This study \\
\hline February 1985 & $\begin{array}{l}19.5^{\circ} \mathrm{N} \\
120.0^{\circ} \mathrm{E}\end{array}$ & 1.5 & $3 d$ & $\begin{array}{l}\text { Pigment } \\
\text { concentration, } \\
\text { CZCS data }\end{array}$ & This study \\
\hline January 1986 & $\begin{array}{l}18.5^{\circ} \mathrm{N} \\
117.5^{\circ} \mathrm{E}\end{array}$ & 2.0 & $3 b$ & $\begin{array}{l}\text { Pigment } \\
\text { concentration, } \\
\text { CZCS data }\end{array}$ & This study \\
\hline
\end{tabular}

concentrations are located near the thermocline. Ocean color satellites detect the pigments in the first optical depth beneath the surface, and may not reflect the deeper chlorophyll maximum layers.

\section{Mechanism for bloom formation}

A major question concerning these observations of winter phytoplankton blooms southwest of the Luzon Strait is: where is the nutrient source that supports the bloom? In the northern coastal waters of the SCS, phytoplankton blooms usually occur in the spring (Lin et al. 1988). In these coastal shelf waters the nutrients may come from benthic regeneration and get mixed up into the euphotic zone or from increased river discharge with the onset of the raining summer monsoon. Winter blooms southwest of the Luzon Strait imply some other sources of nutrients to the euphotic zone in an area where the water is generally deeper than $2500 \mathrm{~m}$. Possible nutrient sources are (1) an upward supply from beneath the mixed layer through vertical mixing, (2) some type of upwelling associated with fronts or eddies, or (3) advection from the Luzon Strait.

Numerical models show a winter upwelling centered at $18^{\circ} \mathrm{N}, 118^{\circ} \mathrm{E}$ because of the strong northeast wind (Liu et al. 1997). From a cruise in December 1990, Shaw et al. (1996) reported a major upwelling region with its center at about $100 \mathrm{~km}$ offshore between 16 and $19^{\circ} \mathrm{N}$, northwest of the Luzon in the SCS, based upon temperature, salinity, and dissolved oxygen concentration. Their study showed that nutrients in the surface waters in the SCS could come from only a few localized upwelling sources. The climatological distribution of temperature and upper ocean heat content supports the existence of this upwelling (Levitus 1984). Results from a general circulation model of the SCS further show that the upwelling off the Luzon Strait occurs between October and January, in agreement with the climatological data (Shaw et al. 1996). The high pigment concentrations in winter are further evidence of upwelling southwest of the Luzon Strait. The location and the season of upwelling match our satellite observations of the phytoplankton blooms. In the upwelled water, nutrients increase rapidly downward (Gong et al. 1992). Therefore, the upwelled water with high nutrients would be an important source of nutrients for the surface water (Shaw et al. 1996). This situation is similar to the 
condition in the Minnan-Taiwan upwelling ecosystem (Qiu et al. 1991).

Wyrtki (1961) developed a model showing that the water exchange between the SCS and the West Philippine Sea is controlled by monsoon-induced circulation. The AVHRR images indicate that high temperature water currents make a loop westward into the Luzon Strait (Fig. 5) in winter. These loop features in the Strait are found during the period of November to March (Farris \& Wimbush 1996), about the same period of the year during which we detected the phytoplankton blooms. Oceanographic conditions in the northern part of the SCS are greatly influenced by Asian monsoons, with strong northeast winds in the winter and lighter southwest winds in the summer (Wang \& Kester 1988, Kester \& Fox 1993, Tang \& Ni 1996). The northeast monsoon begins in September, lasts through March and is at its strongest from November to January (Farris \& Wimbush 1996). We depict the annual monsoon cycle in relation to the Philippines and the SCS in Fig. 7. The northeast monsoon affects the SST and surface ocean currents. These surface currents could carry the Cagayan River (Fig. 1) discharge from north of the Philippines westward to the region of the bloom, in the southwest area of the Luzon Strait. The winter period, however, is the dry season when the Cagayan River flow is at its minimum $(\mathrm{H}$. Yap, University of Philippines, pers comm. ).

In addition to the supply of nutrients that can support a phytoplankton bloom of the type seen in the CZCS images, water column conditions must be suitable to maintain the phytoplankton above their critical depth for sunlight. Fig. 6 shows that even during the winter monsoon period (February 1977) in the region southwest of Luzon, the water column remains stratified within the upper 50 to $60 \mathrm{~m}$, which enables the phytoplankton to remain in the euphotic zone.

\section{CONCLUSIONS}

This study reveals at least 5 occurrences of phytoplankton blooms southwest of the Luzon Strait during the northeast monsoon winter seasons between 1979 and 1986. Four of these blooms were detected by CZCS data. This region is traditionally classified as a low primary production zone. Winter upwelling in northeast monsoon months in that area appears to be the determining factor that brings nutrients to the surface for phytoplankton bloorns.

The use of satellite remote sensing has revealed an area of seasonally high pigment concentration (and presumably of high productivity) in an area of the tropical ocean and at a time of the year (winter) when it had not been previously known or documented. An examination of published oceanographic studies of this region contains hints that there may be a mechanism to enhance productivity in this area (the loop current, the shoaling of the pycnocline), but it appears that many of these studies were not able to map the area completely because they were constrained to work outside the exclusive economic zones (EEZ) of the Philippines.

As near as we have been able to determine from discussions with marine scientists in the Philippines, they were not aware of this high pigment phenomenon. While there is a local fishery on the west coast of Luzon, it uses small coastal vessels and does not extend 100 to $300 \mathrm{~km}$ offshore.

The use of satellite remote sensing has made it possible to get several complete views of the high pigment region and its presence and absence during various months of the year. These views extend into the EEZ of the Philippines. These views are more complete than the fragmentary observations that were detectable from previous oceanographic surveys.

The analysis of the CZCS images show the likely presence of an area of enhanced phytoplankton bio-

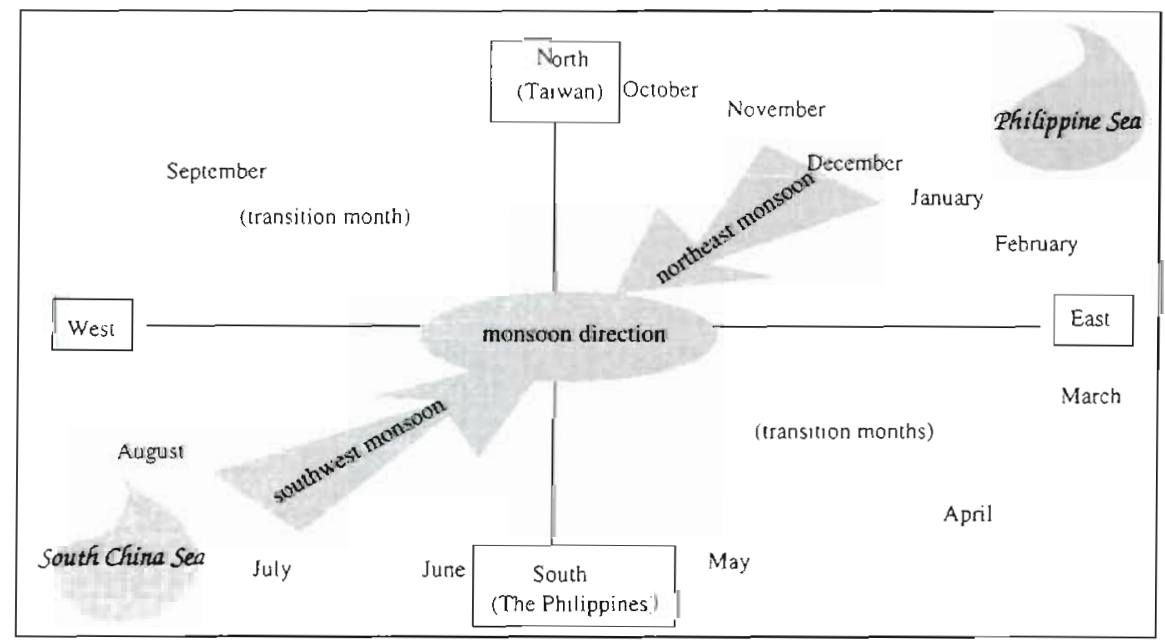

Fig. 7. Asian monsoon cycle in the northern part of the South China Sea: change of wind direction from northeast in the winter to southwest in the summer 
mass between November and February on a significant fraction of the years for which there were images. These observations could provide a basis to conduct more comprehensive oceanographic studies of this area to better understand the mechanisms that lead to high surface water pigment concentrations. The analysis of satellite remote sensing is assisted greatly when direct measurements of the ocean are available.

Acknowledgements. We extend great appreciation to Professor Joe Baker, the Commissioner for the Environment in Canberra (Australia), and Professor Jilan Su of the Second Institute of Oceanography (China) for their comments. We gratefully acknowledge Dr J. Z. Liu of Stanford University, and $\mathrm{Mr}$ Hongpei Chen and Mr Lixin Wong of the Hong Kong University of Science and Technology for their assistance in computer programming. Many thanks to Dr Fernando Gilbes of the University of Puerto Rico for his helpful assistance in data processing and to Dr Sarilee Anderson of the University of California San Diego for her helpful assistance in obtaining the NODC data. Thanks to Dr V. A. Unkefer of the Hong Kong University of Science and Technology for her assistance in technical writing. Acknowledgment to the World Ocean Atlas 1994 CD-ROM Data Set, published by the National Oceanographic Data Center and the Ocean Climate Laboratory, made available through GOODBase, a World Wide Web service of NODC and the SIO JEDA Center. This study was partially funded by Hong Kong's Research Grant Council (Grant No. HKUST $573 / 95 \mathrm{M}$ to I-H.N and D. K. O. Chanj.

\section{LITERATURE CITED}

Barale V, Schlittenhardt PM (1993) Ocean colour: theory and applications in decade of CZCS experience. Kluwer Academic, Dordrecht

Fan JW (1985) Biology in the investigation area. In: South China Sea Institute of Oceanology, Academic Sinica (ed) Report of multidisciplinary investigation of the South China Sea. Science Publishing Company, Beijing, p 317-332 (in Chinese)

Farris A, Wimbush M (1996) Wind-induced Kuroshio intrusion into the South China Sea. J Oceanogr 52:771-784

Gong GC, Liu KK, Liu CT, Pai SC (1992) The chemical hydrography of the South Chin Sea west of Luzon and a comparison with the west Philippine Sea. Acta Oceanogr Taiwan 3(4):587-602

Gordon HR, Clark DK, Brown JW, Brown OB, Evans RH. Broenkow WW (1983) Phytoplankton pigment concentrations in the Middle Atlantic Bight: comparison of ship determination and CZCS estimates. Appl Opt 22:20-35

Gordon HR, Brown OB, Evans RH, Brown JW, Smith RC, Baker KS, Clark DK (1988) A semi-analytic radiance model of ocean color. J Geophys Res 93(D9):10909-10924

Huang LM (1988) Distribution characteristics of chlorophyll a and estimation of primary productivity in the water around Nansha Island. Marine Biology of the South China Sea. China Ocean Press, Beijing, p 261-274

Huang LM (1992) Vertical variations of chlorophyll a and fluorescence values of different areas in South China Sea. Tropic Oceanol 11(4):89-95 (in Chinese)

Huang LM, Chen QC (1989) Estimation of primary productivity and distribution of chlorophyll-a in Luzon Strait. Acta Oceanol Sin 11(1):94-101 (in Chinese)

Kester DR, Fox MF (1993) Chemical and biological remote sensing of the South China Sea: satellite and in situ obser- vation. In: Fang $M$, Liu A (eds) Symposium on remote sensing in environmental research and global change, The Commercial Press (H.K.) Ltd, Hong Kong, p 60-72

Levitus S (1984) Annual cycle of temperature and heat storage in the world ocean. J Phys Oceanogr 14:727-746

Lin YS, Huang L Yuan W (1988) The ecological characteristics of the red tide occurring in Daya Bay of Guangdong in spring. In: Xu GZ, Morton B (eds) Marine biology of South China Sea. China Ocean Press, Beijing, p 241-248

Liu QY, Li W, Xu QC (1997) Interaction between the northeast monsoon and ocean circulation in South Sea. Oceanol Limnol Sin 5(25):493-508 (in Chinese)

Liu XD, Liu CS (1984) Distribution of chlorophyll in the adjacent waters around Xisha-Zhongsha Islands, South China Sea. Nanhai Study (5):63-66 (in Chinese)

Müller-Karger FE, McClain CR, Fisher TR, Esaias WE, Varela $R$ (1989) Pigment distribution in the Caribbean Sea: observations from space. Prog Oceanogr 23:23-64

Pauly D, Christensen V (1993) Stratified models of large marine ecosystems: a general approach and an application to the South China Sea. In: Sherman K, Alexander LM, Gold BD (eds) Large marine ecosystems: stress, mitigation, and sustainability. AAAS Press, Washington, DC, p 148-174

Qiu SY, Hong GC, Lu ZB, Dai QS, Yan YM (1991) MinnanTaiwan bank Fishing Ground is an upwelling fishing ground. In: Hong HS, Qiu SY, Ruan WQ, Hong GC (eds) Minnan-Taiwan bank fishing ground upwelling ecosystem study. Science, Beijing, p 609-618 (in Chinese)

Riley GA (1957) Phytoplankton of the North Central Sargasso Sea. Limnol Oceanogr 2:252-270

Shaw PT (1991) The seasonal variation of the intrusion of the Philippine Sea water into the South China Sea. J Geophys Res 96(C1):821-827

Shaw PT, Chao SY, Liu KK, Pai SC, Liu CT (1996) Winter upwelling off Luzon in the northeastern South China Sea. J Geophys Res 101(C7): 16435-16448

Sverdrup HU, Johnson MW, Fleming RH (1946) The oceans: their physics, chemistry, and general biology. Prentice Hall, New York

Tang DL, Ni IH (1996) Remote sensing of Hong Kong water: spatial and temporal changes of sea surface temperature. Acta Oceanogr Taiwan 35(2):173-186

Tang DL, Ni IH, Müller-Karger FE, Liu ZR (1998) Analysis of annual and spatial patterns of CZCS-derived pigment concentration on the continental shelf of China. Cont Shelf Res 18:1493-1515

Townsend DW, Keller MD, Sieracki ME. Ackleson SG (1992) Spring phytoplankton blooms in the absence of vertical water column stratification. Nature 360:59-62

Townsend DW, Cammen LM, Holligan PM, Campbell DE, Pettigrew NR (1994) Cause and consequences of variability in the timing of spring phytoplankton blooms. DeepSea Res I 41(5/6):747-765

Wang ZD, Kester DR (1988) Seasonal variation in the South China Sea Continental Shelf Water. In: South China Sea Institute of Oceanology Academia Sinica (ed) Selected Oceanic Works, Number 1. China Ocean Press, Beijing, p $81-93$

Wessel P. Smith WHF (1991) Free software help map and display data. EOS Trans. AGU 72:441,445-446

Wessel P, Smith WHF (1995) The generic mapping tools GMT Version 3. Technical reference and cookbook, Monoa, Hawaii

Wyrtki K (1961) Physical oceanography of southeast Asian water. Scientific results of marine investigations of South China and the Gulf of Thailand. Scripps Institution of Oceanography, La Jolla, CA, NAGA Report 2:195 